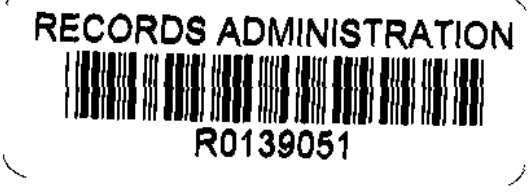

DP-1576

\title{
THORIUM OXALATE SOLUBILITY AND MORPHOLOGY
}

\author{
P. R. MONSON, JR. \\ AND R. HALL
}

\section{TIS FILE RECORD COPY}

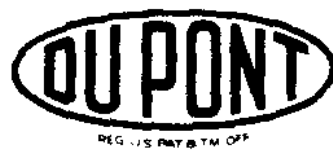

E. 1. du Pont de Nemours \& Co. Savannah River Laboratory Aiken, SC 29808 


\section{DISCLAIMER}

This report was prepared by E. I. du Pont de Nemours and Compeny (Du Pont) for the United States Department of Energy under Contract DE-ACO9-76SRO0001 and is an account of work performed under that Contract. Neither the United States, the United States Depertment of Energy nor Du Pont, nor any of their emplavees. makes any warranty, express or implied, or assumes any legal liability or responsibility for the accuracy, completeness, or usefulness of any information, apparatus, product, or process disclosed herein, or represents that its use will not infringe privately owned rights. Reference herein to any specific commerical product, process, or service by trade name, mark, manufacturer, or otherwise does not necessarily constitute or imply endorsement, recommendation, or favoring of same by Du Pont or by the United States Government or any agency thereof. The views and opinions of authors expressed herein do not necessarily state or reflect those of the United States Government or any ageney

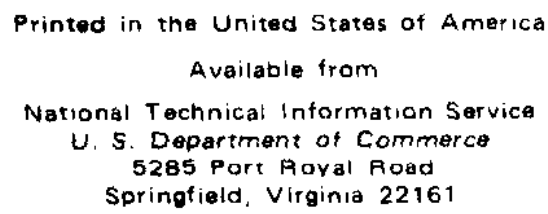

Price: Printed Copy A02; Microfiche A01 
DP-1576

Distribution Category: UC-10

\section{THORIUM OXALATE SOLUBILITY AND MORPHOLOGY}

by

P. R. Monson, Jr. and R. Hall

Approved by

H. D. Harmon, Research Manager

Actinide Technology Division

Publication Date: October 1981

E. I. du Pont de Nemours 8 Co. Savannah River Laboratory Aiken, SC 29808 PREPARED FOR THE U. S. DEPARTMENT OF ENERGY UNDER CONTRACT DE-ACO9.76SR00001 
Thorium was used as a stand-in for studying the solubility and precipitation of neptunium and plutonium oxalates. Thorium oxalate solubility was determined over a range of 0.001 to 10.0 in the concentration parameter $\left[\mathrm{H}_{2} \mathrm{C}_{2} \mathrm{O}_{4}\right] /\left[\mathrm{HNO}_{3}\right]^{2}$. Morphology of thorium oxide made from the oxalate precipitates was characterized by scanning electron microscopy. The different morphologies found for oxalate-lean and oxalate-rich precipitations were in agreement with predictions based on precipitation theory. 


\author{
Int roduct ion 5 \\ Experimental Methods 5 \\ Equilibrium Solubility 5 \\ Analytical Determination of Thorium 6 \\ Scanning Electron Microscopy 7 \\ Solubility of Thorium Oxalate 7 \\ Morphology of Thorium Oxide 9 \\ References $\quad 12$
}


(Blank)

$-4-$ 
THORIUM OXALATE SOLUBILITY AND MORPHOLOGY

\section{INTRODUCTION}

Several actinide products are recovered at the Savannah River Plant by oxalate precipitation. For example, neptunium is precipitated as $\mathrm{Np}$ (IV) oxalate and calcined to $\mathrm{NpO}_{2}$. Neptunium dioxide is mixed with powdered aluminum and pressed into billets for fabrication into targets for reactor irradiation to produce ${ }^{238} \mathrm{Pu}$. Targets are successfully made from $\mathrm{NpO}_{2}$ powder with an average size of $11 \mu \mathrm{m}$ and aluminum powder of $27 \mu \mathrm{m}$. However, occasionally difficulties in powder blending have resulted in hard spots and density gradients in some targets. A closer match of $\mathrm{NpO}_{2}$ and aluminum particle properties (size and morphology) would result in a more homogeneous blend and would help to alleviate these difficulties. Presently, the aluminum specifications are set and cannot be changed easily. This study provided fundamental actinide oxalate solubility data needed for the detailed control of particle size and morphology in the precipitation process.

In the study, thorium was used as a stand-in for neptunium and plutonium for the following reasons: 1) thorium is not as radioactive as neptunium or plutonium and can be handled safely outside of a glove box, 2) thorium chemistry is similar to the other actinides in the 4+ valence state, 3) techniques and instruments can be developed on a nonradioactive system, and 4) thorium could be used to test full-scale process equipment.

\section{EXPERIMENTAL METHODS}

\section{Equilibrium Solubility Determination}

The equilibrium solubility of thorium oxalate/nitric acid solutions at $23^{\circ} \mathrm{C}$ was determined by two methods. In the first method, pure thorium oxalate was dissolved in oxalic acid/nitric acid solutions containing $0.01 \mathrm{M}$ to $11.0 \mathrm{M}$ nitric acid. These solutions were agitated for 6 to 7 days to ensure equilibrium solubility. I

In the second method, thorium oxalate was precipitated in a "direct strike" (addition of oxalic acid to thorium nitrate) with a 20 to $40 \%$ excess oxalic acid in $0.5 \mathrm{M}$ to $8.0 \mathrm{M}$ nitric acid. These solutions were agitated 10 to 14 hours before analysis. 


\section{Analytical Determination of Thorium}

Thorium concentrations were determined by the arsenazo-III spectrophotometric technique developed by Savvin ${ }^{2}$ and perfected at SRL by E. W. Baumann. ${ }^{3}$ This analytical method had to be modified to determine the actinides in nitric acid because nitrous acid in the nitric acid destroyed the arsenazo-III reagent and rendered the arsenazo-III-thorium complex unstable. The nitrous acid was removed by pretreating the $4 \mathrm{M} \mathrm{HNO}_{3}$, used to acidify the complex with 1 volume \% of $0.3 \mathrm{M}$ sulfamic acid.

The absorbance was measured at $663 \mathrm{~nm}$ in a $1-\mathrm{cm}$ cell with water as reference. A spectrum of the reagent and its thorium complex is shown in Figure 1. A calibration curve, Figure 2, was generated by dilution of a standard thorium nitrate solution. This rechnique has a sensitivity of $1 \mathrm{\mu g} / \mathrm{mL}$ for thorium and is also applicable to other actinides in the $4+$ valence state.

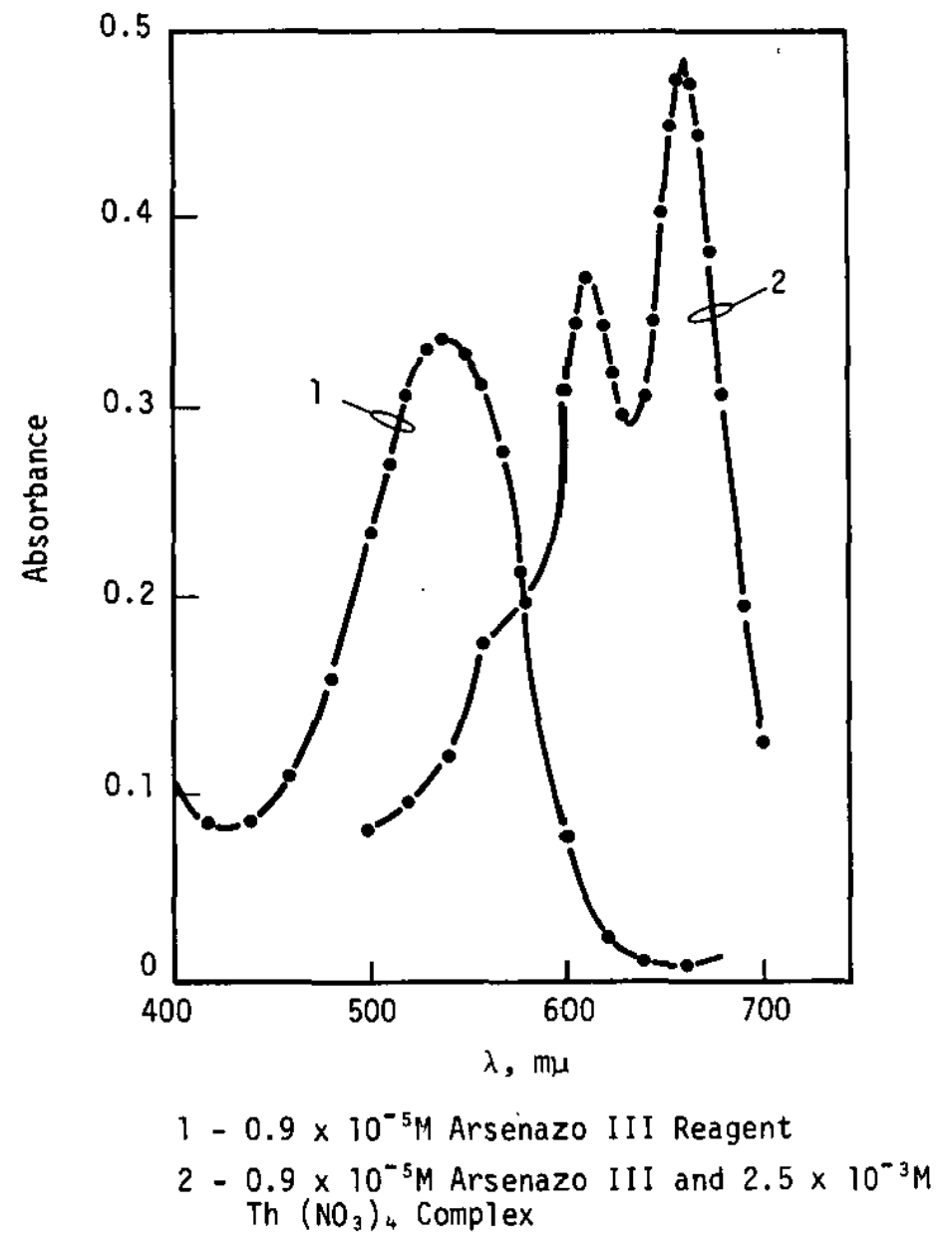

FIGURE 1. Absorption Spectrum of Arsenazo-III/Th Complex From Reference 2 


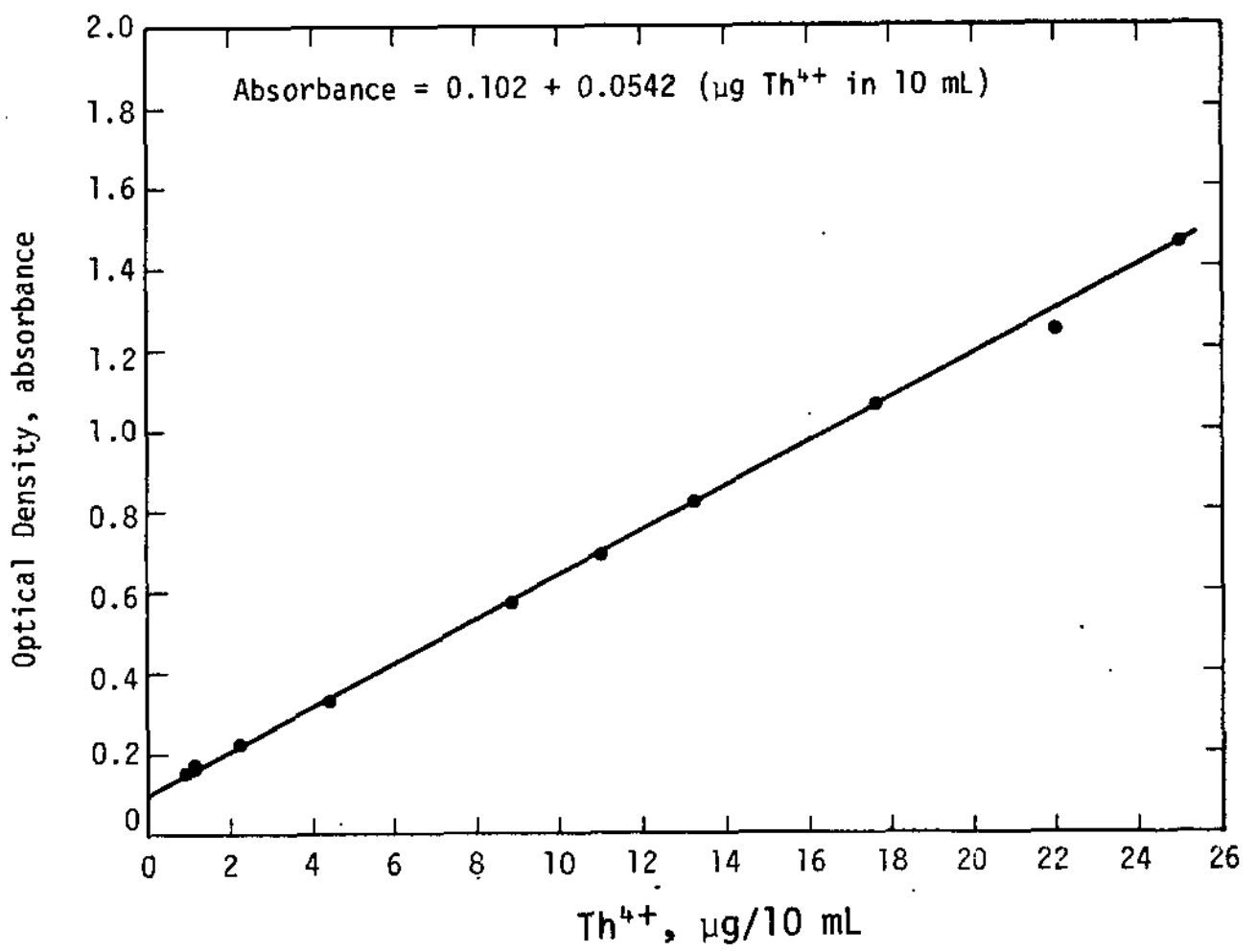

FIGURE 2. Th(IV) Calibration Curve

\section{Scanning Blectron Microscopy}

Thorium oxide for SEM (scanning electron microscope) analysis was prepared by calcining the oxalate at $600^{\circ} \mathrm{C}$ for 4 to 6 hours.

\section{SOLUBILITY OF THORIUM OXALATE}

A plot of the thorium oxalate solubility data is given in Figure 3. The dat a are also tabulated in Table 1 to show the actual oxalic acid and nitric acid concentrations along with the concentration parameter, $f_{p}$, used as the abscissa in Figure 3 . This parameter is proportional to the free oxalate ion in solution and is defined in Equation 1.

$$
f_{\rho}=\frac{\left[\mathrm{H}_{2} \mathrm{C}_{2} \mathrm{O}_{4}\right]}{\left[\mathrm{H}^{+}\right]^{2}}=\frac{\left[\mathrm{C}_{2} \mathrm{O}_{4}{ }^{2-}\right]}{\mathrm{K}}
$$

where $K$ is the dissociation constant for oxalic acid. 


\section{TABLE 1}

Thorium Oxalate Solubility in Oxalic Acid/Nitric Acid Solutions at $23^{\circ} \mathrm{C}$

\begin{tabular}{|c|c|c|c|}
\hline $\mathrm{H}_{2} \mathrm{C}_{2} \mathrm{O}_{4}, \mathrm{M}$ & $\mathrm{HNO}_{3}, \mathrm{M}$ & $\mathrm{fp}\left(\left[\mathrm{H}_{2} \mathrm{C}_{2} \mathrm{O}_{4}\right] /\left[\mathrm{H}^{+}\right]^{2}\right)$ & $\mathrm{Th}^{4+}$ Solubility, $\mathrm{mg} / \mathrm{L}$ \\
\hline 0.41 & 10.9 & 0.003 & 320 \\
\hline 0.50 & 8.2 & 0.007 & 7.5 \\
\hline 0.42 & 5.1 & 0.016 & 3.7 \\
\hline 0.37 & 4.1 & 0.022 & 1.9 \\
\hline 0.54 & 3.2 & 0.053 & 2.3 \\
\hline 0.57 & 1.7 & 0.197 & 0.7 \\
\hline 0.18 & 0.58 & 0.55 & 1.6 \\
\hline 0.81 & 0.28 & 10.3 & 1.8 \\
\hline
\end{tabular}

Solubility increases to the left side (oxalate lean) of the minimum in the solubility curve because of soluble cationic complexes ${ }^{4}$ such as $\mathrm{Th}\left[\mathrm{C}_{2} \mathrm{O}_{4}\right]^{2+}$. As more oxalate is added, a minimum solubility is reached corresponding to the stoichiometric amount of oxalate, $\mathrm{Th}\left[\mathrm{C}_{2} \mathrm{O}_{4}\right]_{2}$. However, as even more oxalate is added, the solubility increases because soluble anionic complexes ${ }^{4}$ such as $\operatorname{Th}\left[\mathrm{C}_{2} \mathrm{O}_{4}\right]_{3}{ }^{2-}$ and $\operatorname{Th}\left[\mathrm{C}_{2} \mathrm{O}_{4}\right]_{4}{ }^{4-}$ form. Similar solubility curves exhibiting a minimum have been observed for neptunium, plutonium, ${ }^{6}$ and thorium. 4

Thorium solubility was increased slightly (from 1.8 to $2.7 \mathrm{mg} / \mathrm{L}$ ), on the oxalate-rich side of the curve, by adding sodium oxalate to a solution which had a fp of 20 . However, in the absence of nitric acid (extremely oxalate rich, $f p \cong \infty$ ), the thorium oxalate solubility in an oxalic acid/ammonium oxalate solution was $2,000 \mathrm{mg} / \mathrm{L}$. 


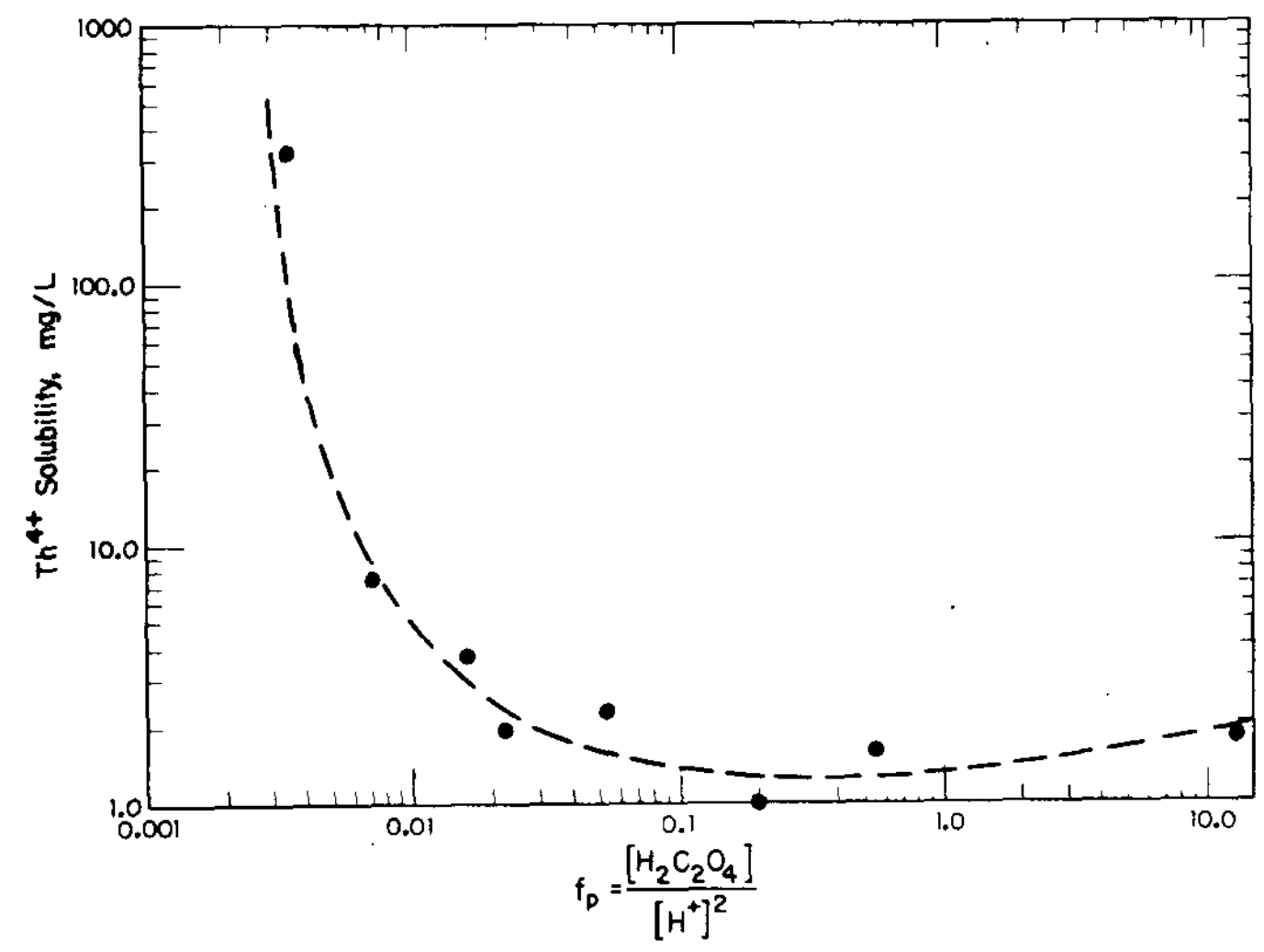

FIGURE 3. Thorium Oxalate Solubility

\section{MORPHOLOGY OF THORIUM OXIDE}

The $\mathrm{ThO}_{2}$ morphology was determined for precipitations carried out such that the reaction was at all times either on the oxalatelean or oxalate-rich side of the solubility curve with no mixed (oxalate-lean/oxalate-rich) precipitate. Figure 4 is a SEM photograph of $\mathrm{ThO}_{2}$ from the oxalate-lean or "direct strike" precipitation revealing a square plate morphology similar to that observed in neptunium or plutonium. ${ }^{7}$ The particle size from SEM analysis is about $25 \mu \mathrm{m}$ square. Characteristics of ThO 2 from an oxalate-rich precipitation are shown in Figure 5. This product was prepared by reprecipitation of the supernate from the oxalic acid/ammonium oxalate solution with additional oxalic acid. This oxalate-rich precipitation gives a completely different morphology of fine $(0.5 \mathrm{~mm}$ diameter) spherical/hemispherical particles.

This change in morphology, as a function of controlled precipitation conditions, agrees with current theoretical predictions. Particles are 50 times larger for the oxalate-lean precipit ation because less oxalate ion is available; thus, fewer nuclei form and grow less before precipitating. In the oxalate-rich 
case, the solution is greatly supersaturated with soluble thorium oxalate complexes containing excess oxalate and reaches a point of rapid nucleation and precipitation with little time for crystal growth.

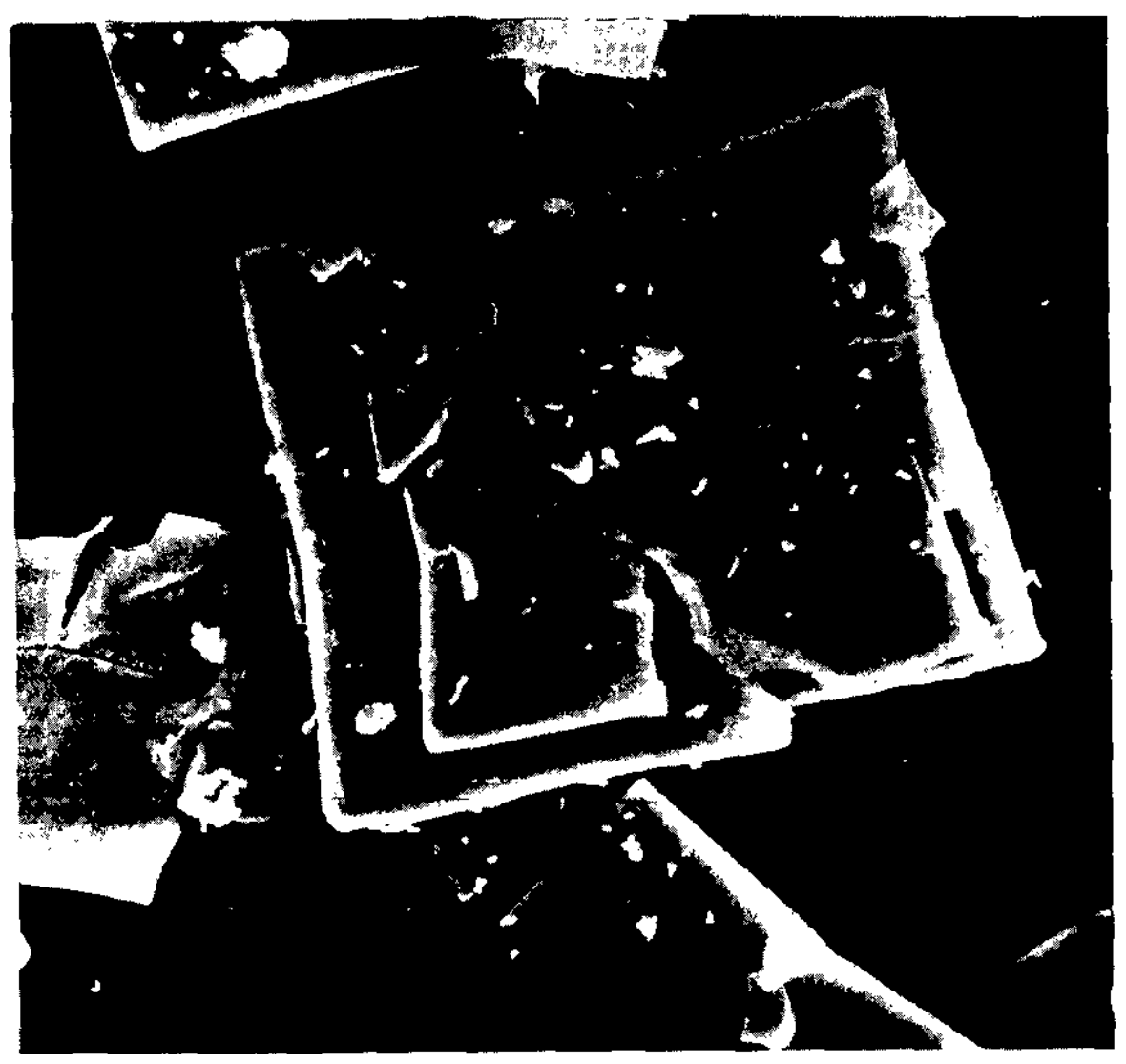

PIGURE 4. SEM of Thorium Oxide $\left(\mathrm{ThO}_{2}\right)$ - "Direct Strike", Oxalate-Lean Precipitation 


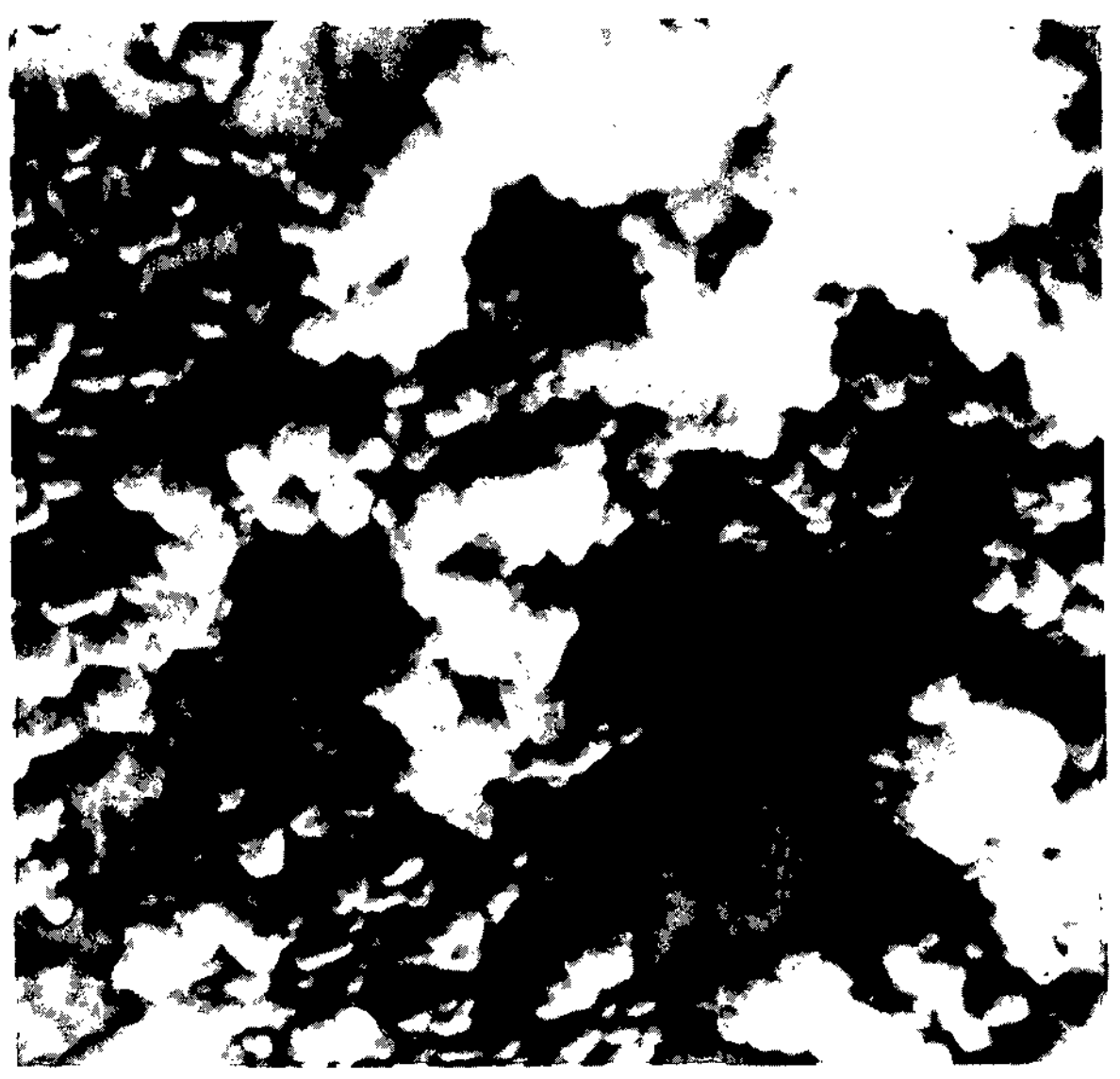

FIGURE 5. SEM of Thorium Oxide $\left(\mathrm{ThO}_{2}\right)$ - Precipitation from Oxalate-Rich Region 


\section{REFERENCES}

1. A. G. Kurnakova and L. K. Shubochkin. Russ. J. Inorg. Chem. $\underline{8}(5), 647$ (1963).

2. S. B. Savvin. Talanta 8,673 (1961).

3. E. W. Baumann. USDOE Report DP-1560, E. I. du Pont de Nemours \& Co., Savannah River Laboratory, Aiken, SC (1980).

4. A. I. Moskvin and L. N. Essen. Russ. J. Inorg. Chem. 12(3), 359 (1967).

5. J. A. Porter. USAEC Report DP-591, E. I. du Pont de Nemours \& Co., Savannah River Laboratory, Aiken, SC (1961).

6. C. J. Mandleberg, K. E. Francis, and R. Smith. J. Chem. Soc. 1961,2464 .

7. D. T. Rankin, G. A. Burney, P. K. Smith, and R. D. Sisson, Jr. Ceramic Bulletin 56(5), 478 (1977). 